\title{
ECONOMIC PROFITABILITY OF SWEET PEPPER PRODUCTION UNDER DIFFERENT IRRIGATION LEVELS AND POLYETHYLENE MULCH IN A PLASTIC GREENHOUSE
}

\author{
Mohamed A. A. Abdrabbo', Assem A. A. Mohamed ${ }^{2}$, Fadl. A. Hashem ${ }^{3}$, Ahmed. S. A. Hegab ${ }^{4}$ \\ ${ }_{1,2,3,4}$ Central Laboratory for Agricultural Climate \\ abdrabbo@yahoo.com, \\ assem20000@yahoo.com \\ fadl_hashem@yahoo.com, \\ ahmedsabry1988@yahoo.com
}

\begin{abstract}
Field experiment was conducted, during two successive seasons of 2014- 2015 and 2015- 2016, at Dokki protected agricultural site, Giza Governorate, Egypt, to study the profitability of different applied irrigation levels and polyethylene (PE) mulch on plant growth and yield of sweet pepper, (Capsicum annum L.) cv. Godion F1, under plastic house condition. Three irrigation levels (0.50, 0.75 and 1.00) of crop evapotranspiration (ETc), using drip irrigation system and three PE mulch treatments (transparent, black and control) were applied. Data revealed that black PE recorded the highest values of early and total fruit yield per plant during the two seasons. Increasing water level up to 1.00 (ETc) enhanced yield with different PE mulch treatments, while water use efficiency (WUE) decreased with increasing water level. However, Using 0.50 (ETc), with different PE mulches increased WUE compared to using 0.75 (ETc) or 1.00 (ETc).

The economic assessment of costs and returns from different treatments were calculated. It was found that the average yield was higher in 1.00 ETc with black mulch. Gross margin per $540 \mathrm{~m}^{2}$ were analysed using yield data, price structures and production costs. The 1.00 (ETc) with black mulch had the highest gross margin which is USD 416.8 and USD 533 (1 USD = 9 Egyptian pound) for the first and second seasons, respectively. The benefit cost ratios (BCRs) per $540 \mathrm{~m}^{2}$ were analysed, and 1.00 (ETc) with black mulch had the highest BCR with 1.36 in the first season and 1.45 in the second season.
\end{abstract}

Keywords: Economic Profitability, Etc, Gross Margin, Sweet Paper, WUE.

(JEL Classification: $Q 01, Q 12, Q 19$ )

\section{INTRODUCTION}

Irrigation water is gradually becoming scarce not only in arid regions but also in the regions where rainfall is sufficient. Therefore, water saving and conservation is essential to support agricultural activities (Abdrabbo et al., 2009). Efficient use of available fresh water is becoming more important. Agronomic measures such as varying tillage practices, mulching and anti-transparent can reduce the demand for irrigation water and improve irrigation water use efficiency (Farag et al., 2010). The mulch determines its energy-radiating behavior and its influence on the microclimate around the plant. Black, transparent and white mulches are used in the commercial production of vegetable crops today all over the world (Abdrabbo et al., 2010). Transparent and black mulches promote a relatively higher temperature at the soil surface, increase soil heat flux and, as a consequence, the minimum and maximum soil temperature are increased than bare soil treatments (Abdrabbo et al., 2009; EI-Dolify et al., 2016). The beneficial responses of plants to plastic mulch such as improving fruit yields, earlier production and better fruit quality; have been studied by many authors (Bonnano and Lamont, 1987; Zakher and Abdrabbo, 2014). Additional benefits of plastic mulches are their ability to conserve soil moisture (Lamont, 1993). Using transparent polyethylene mulch, installed over the soil surface to reduce the water evaporation, increase air temperature around plant roots. Furthermore, their usage has been associated with 
increased plant growth, higher yields as well as earliness of harvest (Abdrabbo et al., 2014). Despite the wide use of plastic mulches for vegetable crops production, most studies on irrigation have been conducted on bare soil production systems (Kirda et al., 2004). Results from those studies may not apply to regular horticulture practices (mainly raised beds covered with black plastic mulch) because using mulch serves as a barrier for water evaporation from soil surface (Farrag et al., 2016). Liakatas et al. (1986) reported that maximum soil heat flux was up to $67 \%$ higher under transparent mulch in comparison to the black mulch. White polyethylene used in this study trended to increase maximum temperature compared to the other opaque mulches (black and co-extruded white-on-black polyethylene). This increase probably occurred because white polyethylene is not completely opaque. Using polyethylene mulch improves vegetative growth parameters, plant length, leaves area and chlorophyll content of plants (Abdrabbo et al., 2005).

Rajbir Singh et al. (2009) reported that drip irrigation to tomato at 80 per cent ET resulted in higher net returns (Rs $34431 /$ ha) and benefit cost ratio (1.76) compared to 100 and 60 per cent ET. However, net returns (Rs 51386/ ha) and benefit cost ratio (2.03) were further increased when drip irrigation to tomato at 80 per cent ET was coupled with polyethylene mulch compared to other treatments.

The main objective of this study was to evaluate the economic feasibility of sweet pepper production under different irrigation levels and polyethylene mulch in a plastic greenhouse.

\section{MATERIALS AND METHODS}

The experiment was carried out at Dokki protected agricultural site, Giza governorate, Egypt. The treatments comprised of:

- Three applied irrigation levels $0.50,0.75$ and 1.00 of the (ETc), the ETo was estimated using RH\% equation (Abou Hadid and El-Beltage, 1992) as follow: $\mathrm{ET}_{0}=5.654-0.059 *(\mathrm{RH})$ Where ET0 $=$ estimated evapotranspiration and $\mathrm{RH}=$ average daily relative humidity. Water was applied using drip irrigation system.

- Three polyethylene (PE) mulch treatments (transparent, black and no cover (control)).

The experiment was designed in a split plot arrangement with three replicates. Irrigation levels were in the main plots, while PE mulch was allocated in the sub plot. Each sub plot area was 10 square meters (one meter width $\mathrm{x}$ ten meter length). Dates of transplanting were October 12, 2014 and October 15, 2015 for first and second seasons, respectively. Samples of five plants from each experimental plot were taken to determine growth parameters at the end of season (mid of April 2015 and 2016) as follows: plant length, number of leaves per plant, leaf area and fruit weight per plant. For mineral analysis, the dried young mature leaves were digested in sulphuric acid and hydrogen peroxide according to the method described by Allen (1974). Total nitrogen was determined by Kjeldahl method according to the procedure described by FAO (1980). Phosphorus content was determined using spectrophotometer according to Watanabe and Olsen (1965). Potassium content was determined photo-metrically using flame photometer as described by Chapman and Pratt (1961). The permanent wilting point (PWP) and field capacity (FC) of the trial soil were determined according to Israelsen and Hansen (1962). The soil physical properties results were in table 1 .

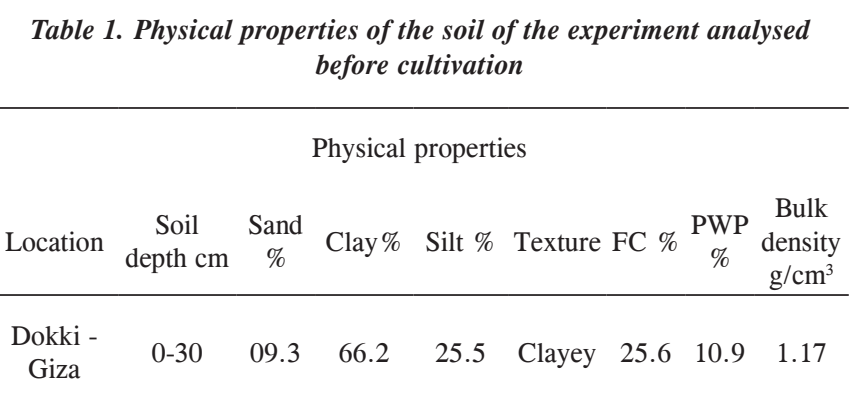

Soil temperature was measured by soil thermometer at $15 \mathrm{~cm}$ depth; it was recorded daily at mid-day from first of November till the end of April, during the two seasons. The total amount of drip irrigation was applied by water flow meter for each treatment (EC of water irrigation $0.45 \mathrm{dS} / \mathrm{m}$ ). The greenhouse dimensions were $(60 \mathrm{~m}$ length, $9 \mathrm{~m}$ width and $4 \mathrm{~m}$ height). The number of sweet pepper plant per square meter was 2.22 plants. The (WUE) was calculated according to FAO (1982) as follows: The ratio of crop yield (y) to the total amount of irrigation water use in the field for the growth season (IR), WUE $\left(\mathrm{Kg} / \mathrm{m}^{3}\right)=\mathrm{Y}(\mathrm{kg}) / \mathrm{IR}\left(\mathrm{m}^{3}\right)$.

Production costs and profitability analysis has been the fundamental tool for growers and investors to do investment analyses and make decisions, conducting business transactions, and developing risk management strategies. Inputs and prices were collected from cooperating growers and supply and equipment dealers. The benefit cost analysis (BCA), as an economic analysis tool for decision making and project evaluation, was chosen as the most appropriate economic method to be use. BCA is a widely used tool for comparing alternative courses of action by reference to the net benefits that they produce, and comparing a base case (no change) with the proposed option. BCA's for multiple projects can be compared to determine which project has a higher economic return relative to the others with higher BCA's indicating higher return (Gittinger, 2003).

\section{RESULTS AND DISCUSSIONS}

\section{Soil temperature}

Average weekly maximum and minimum soil temperature $\left({ }^{\circ} \mathrm{C}\right)$ at $15 \mathrm{~cm}$ depth under different mulch treatments in November, December, January, February, March and April are shown in figures (1) and (2), respectively. During the growing seasons, the highest maximum soil temperature, from 1st November till the end of April, was found under the transparent mulch (Fig. 1). Generally, the PE mulch had higher temperature than control by $1.5-2.5^{\circ} \mathrm{C}$. Highest minimum temperature was recorded under black mulch followed by the white mulch, while the control treatment had the lowest 
minimum temperature.

Fig. 1. The average weekly maximum soil temperature $\left({ }^{\circ} \mathrm{C}\right)$ at $15 \mathrm{~cm}$ depth under different mulch treatments during seasons of 2014- 2015

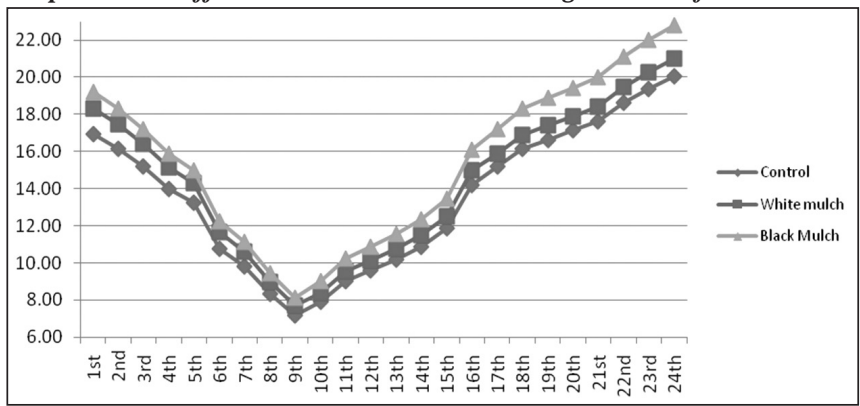

and 2015- 2016 from 1st November till April (24 weeks)

Fig 2. The average weekly minimum soil temperature $\left({ }^{\circ} \mathrm{C}\right)$ at $15 \mathrm{~cm}$ depth under different mulch treatments during seasons of 2014- 2015

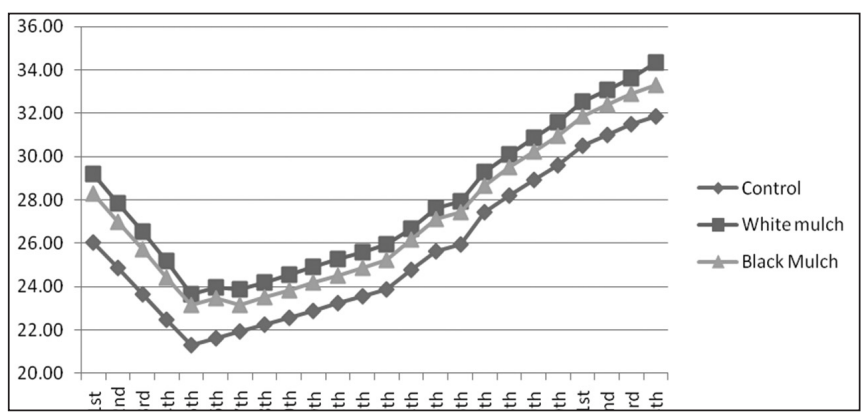

and 2015-2016, from 1st November till April (24 weeks)

The obtained results are in agreement with those of Abdrabbo et al. (2015); Abdrabbo et al. (2010); Abdrabbo et al. (2009); Kirda et al. (2004); Lamont, (1993). Moreover, the advantage of transparent films, which produced a considerable build up of heat in the soil during the day because of better short wave infrared radiation, thus provides the maximum of heat. Under black plastic film, heat was dispatched by conduction, half going into the soil and half into the air space; the soil was therefore heated up quite slowly. While with transparent film, the film transmitted practically the whole solar radiation that became absorbed by the soil; the soil was therefore heated up more quickly (Abdrabbo et al., 2009; Lamont, 1993).

\section{Vegetative characteristics}

The obtained results in table 2 revealed that irrigation levels and mulch treatments significantly affected vegetative characteristics (plant length, number of leaves and total leaf area) in the two growing seasons. The 1.00 ETc treatments produced the highest vegetative characteristics. The $0.75 \mathrm{ETc}$ came in the second rank, while $0.50 \mathrm{ETc}$ produced the lowest vegetative characteristics. Increasing vegetative characteristics under 1.00 ETc irrigation level could be attributed to the suitable irrigation quantity, especially in the early stage of crop growth, which enhanced a deeper and more extensive root system (Marouelli and Silva, 2005; Ngouajio et al., 2007; EI-Dolify et al., 2016). Regarding to the mulch treatments, data indicated that black PE mulch resulted in the highest vegetative characteristics during the two seasons. The lowest plant length, number of leaves and total leaf area were obtained by control treatment (bare soil).

The interaction among different irrigation levels and PE mulch treatments were significant for vegetative characteristics during the two studied seasons. The highest vegetative growth was preceded by 1.00 ETc combined with black mulch. Followed by $1.00 \mathrm{ETc}$ combined with transparent mulch. The obtained results are in agreement with those of Abdrabbo et al (2010); Ngouajio et al. (2007); Soltani et al. (1995), who revealed that mulching has contributed positively to improving growth and productivity. Although, clear plastic mulch may result in an increase in soil temperature, the presence of light led to the disadvantage of weed growth. While, the absence of light with black plastic did not allow photosynthesis of weeds under the film and therefore weed growth was suppressed (Abdrabbo et al., 2010; Farag et al.., 2010; Zakher and Abdrabbo, 2014).

\section{Yield}

Data in table 3 showed that using 1.00 ETc irrigation level increased the sweet pepper fruit weight per plant compared to the other irrigation treatments during the two growing seasons. The $0.75 \mathrm{ETc}$ came in the second rank. The higher yield production under $1.00 \mathrm{ETc}$ may be due to proper balance of moisture in plants, which creates favorable conditions for nutrients uptake, photosynthesis and metabolites translocation. Other possibility was increasing available water and nutrients uptake, which ultimately accelerated the rate of vegetative growth and yield (Abdrabbo et al., 2009; Hashem et al., 2014; Abdrabbo et al., 2014; EI-Dolify et al., 2016). Regarding the effect of PE mulch treatments the obtained data revealed that black PE recorded the highest values of yield per plant in the two studied seasons. These results was in agreement with those obtained by Abdrabbo et al., 2009; EI-Dolify et al. (2016); Farrag et al. (2016), who found that using PE mulch increases plant root zone temperature, which have an important role in plant growth and productivity. Black and transparent PE mulches increase vegetable crops growth and productivity compared to bare soil; this increase has been reported especially in cold season, where soil temperature is the limiting factor for plant growth (Farrag et al., 2016). Referring to the interaction effect between irrigation level and PE mulch treatments, the obtained data indicated that increasing irrigation level led to increase sweet pepper yield under tested PE mulch up to 1.00 ETc. The highest sweet pepper yield was obtained by 1.00 ETc with black PE mulch followed by 1.00 with transparent PE mulch. The lowest yield was obtained by control treatment with different irrigation levels. Reduction in irrigation requirement as well as consumptive use due to mulching at a particular irrigation schedule is a definite advantage of mulching (Zakher and Abdrabbo et al., 2014; EI-Dolify et al., 2016). Sustained moisture supply by using proper water quantity with mulched situation was enhanced plant yield. The irrigation water supply, irrespective of irrigation methods, was retained in the soil and efficiently distributed for crop growth. This has enabled the crop not to distinguish significantly between the levels of irrigation it received, once the crop was mulched. 
Furthermore, using mulches with vegetable crops under unheated plastic house resulted in an increase in vegetative growth i.e. plant length, leaf number, leaf area, and total fruit yield of plants. These results are in agreement with those reported by Farag et al (2010). Increased yield could be largely attributed to the increase in soil temperature due to application of black or transparent mulch treatments, which resulted in enhancement of soil environment around plant roots, which led to increasing plant vegetative growth, and hence increasing nutrient absorption and uptake (Abdrabbo et al., 2009; Abdrabbo et al., 2010; Abdrabbo et al., 2015).

Table 2. Sweet pepper plant length, number of leaves and total leaf area per plant as affected by different irrigation levels and mulch treatments during seasons of 2014- 2015 and 2015- 2016

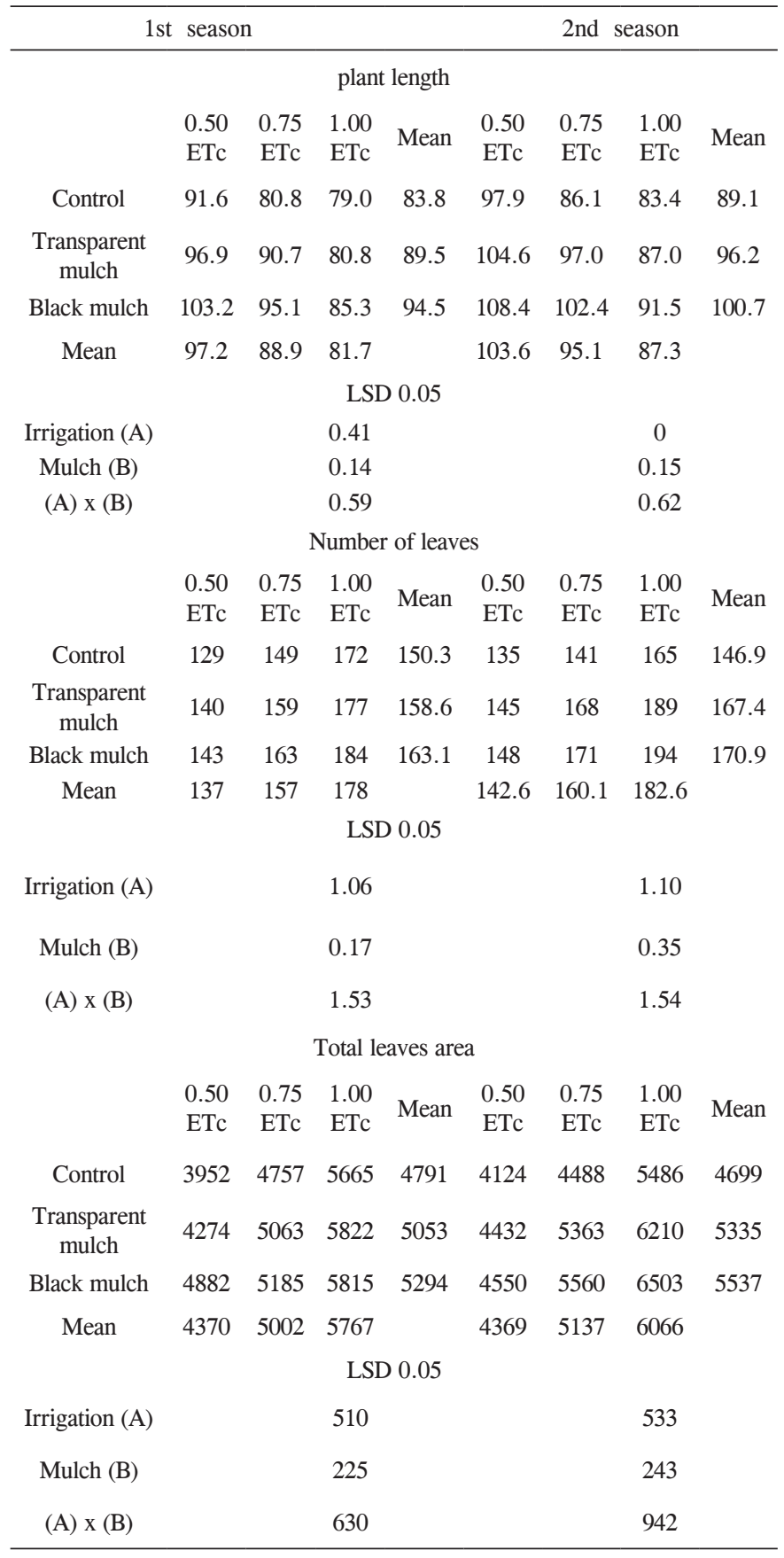

\section{Plant elemental content}

Data in table 4 showed that the applications of different irrigation levels and mulch treatments significantly affected the uptake of NPK by sweet pepper plant during the two growing seasons. Using 0.50 of ETc increased the NPK percentage of sweet pepper fourth leaf followed by $0.75 \mathrm{ETc}$, while the lowest NPK percentage was obtained by 1.00 ETc. The increasing uptake of NPK by 0.50 ETc may be due to the dilution effect (increase plant biomass at a constant nutrient stock) then the big vegetative growth will dilute the nutrient percentage in plant leaf and second are nutrient movements toward fruits or other plant organs which mean higher productivity led to decrease the percentage of nutrient of sweet pepper plant leaf (Abdrabbo et al., 2005).

Table 3. Sweet pepper fruit weight per plant as affected by different irrigation levels and mulch treatments during seasons of 2014- 2015 and 2015- 2016

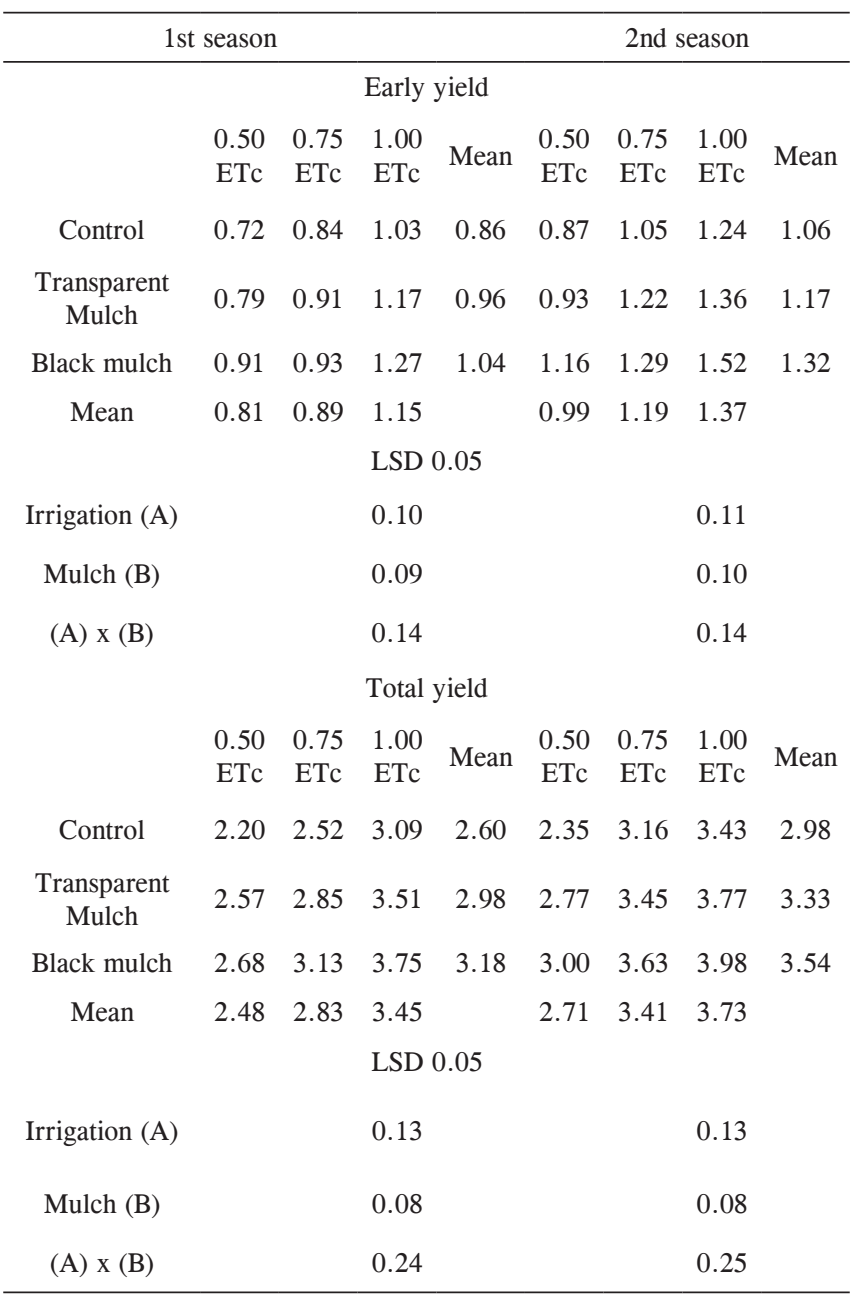

Mulch treatments significantly affected the percentage of NPK in sweet pepper leaf. Transparent PE resulted in the highest values of NPK percentage followed by black PE mulch. The lowest NPK percentage was obtained by control (bare soil) treatment during the two seasons. Regarding the interaction effect among irrigation and mulch, the highest NPK percentage was obtained by 0.50 ETc combined with transparent PE mulch followed by $0.50 \mathrm{ETc}$ with black mulch. The lowest NPK percentage was obtained by control treatment with different irrigation levels during both seasons. Increased yield could be 
largely attributed to increase in soil temperature at $15^{\circ} \mathrm{C}$ due to application of transparent or black mulch covers. These resulted in enhancement of soil environment around roots of sweet pepper plants that led to enhancing plant growth, and hence improve nutrient absorption and uptake (Abdrabbo et al., 2009).

These results were in line with those obtained by Pan et al. (1999); Fonsecal et al. (2003). Optimal root zone temperature with availability of water allow for adequate root function including better uptake of water and nutrients. Plant nutrient uptake, plant growth and yield under mulch fit a quadratic relationship with root zone temperature (Abdrabbo et al., 2014). Using of proper water quantity, especially in clayey soil, allows plants to use water and nutrients from deeper soil, thus enhance water and nutrients use efficiency, with a decline in nitrogen leaching. Excess irrigation not only reduces crop productivity, but also increases nutrient leaching and environmental hazards (EI-Dolify et al., 2016).

Table 4. NPK contents in sweet pepper leaf as affected by different irrigation levels and mulch treatments during seasons of 2014- 2015 and 2015- 2016

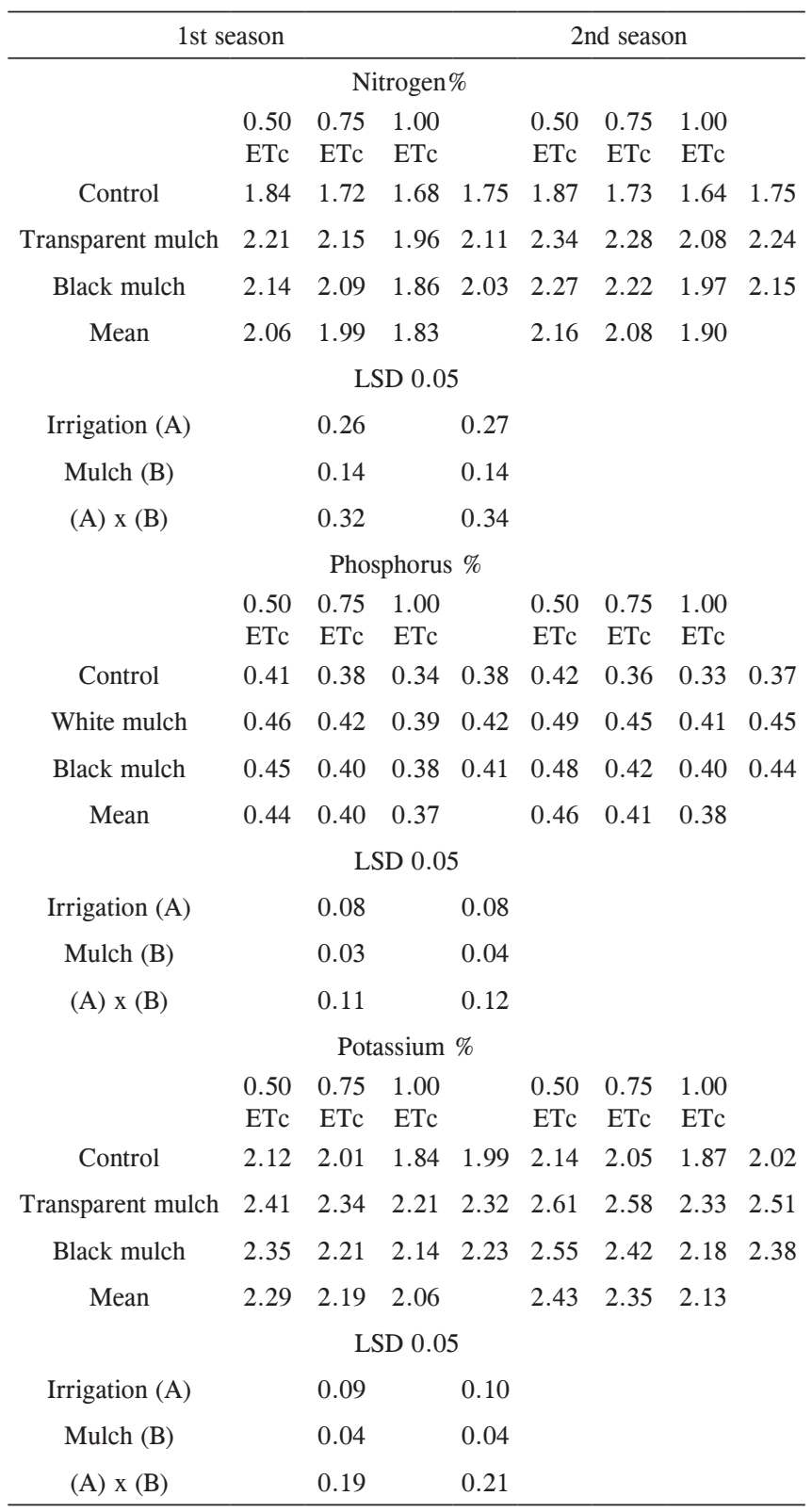

\section{Water Use Efficiency (WUE)}

Data in table 5 showed that increasing irrigation quantity up to 1.00 (ETc) led to the decrease of WUE for all irrigation treatments. The highest WUE obtained by 0.50 (ETc). Regarding the effect of different mulch treatments on WUE, data showed that were significant differences between treatments, using PE mulch led to increasing WUE during the two tested seasons. There was a significant interaction among irrigation and mulch treatments for WUE. The highest WUE obtained by 0.50 (ETc) combined with black PE mulch. The 1.00 (ETc) combined with control treatment had the lowest WUE during the two studied seasons. These results were in line with those obtained by Kirda et al. (2004); Abdrabbo et al. (2009); Farag et al. (2010); Hashem et al. (2014); Zakher and Abdrabbo (2014); Abdrabbo et al. (2015); EI-Dolify et al. (2016); Farrag et al. (2016).

Table 5. Water use efficiency as affected by different irrigation levels and mulch treatments

\begin{tabular}{|c|c|c|c|c|c|c|c|c|}
\hline \multicolumn{9}{|c|}{ WUE } \\
\hline & 0.50 & 0.75 & 1.00 & \multirow{2}{*}{ Mean } & 0.50 & 0.75 & 1.00 & \multirow{2}{*}{ Mean } \\
\hline & ETc & ETc & ETc & & ETc & ETc & ETc & \\
\hline Control & 7.34 & 5.60 & 5.15 & 6.03 & 7.58 & 6.80 & 5.54 & 6.64 \\
\hline $\begin{array}{c}\text { Transparent } \\
\text { Mulch }\end{array}$ & 8.57 & 6.33 & 5.85 & 6.92 & 8.92 & 7.42 & 6.09 & 7.48 \\
\hline Black mulch & 8.93 & 6.95 & 6.25 & 7.37 & 9.67 & 7.81 & 6.41 & 7.97 \\
\hline Mean & 8.28 & 6.29 & 5.75 & & 8.73 & 7.34 & 6.01 & \\
\hline \multicolumn{9}{|c|}{ LSD 0.05} \\
\hline Irrigation (A) & 0.16 & \multicolumn{3}{|c|}{0.17} & & & & \\
\hline Mulch (B) & 0.10 & \multicolumn{3}{|c|}{0.11} & & & & \\
\hline$(\mathrm{A}) \times(\mathrm{B})$ & 0.29 & \multicolumn{3}{|c|}{0.30} & & & & \\
\hline
\end{tabular}

\section{ECONOMIC CONSIDERATIONS}

\section{Total costs of production}

The details of total cost components of sweet pepper production under various irrigation levels with different mulch treatments in USD, during the two production seasons are given in Table 6.

There were almost no significant differences in costs between irrigation levels and PE mulches of sweet pepper for the two production seasons. The only item that varied was value of irrigation at $50 \%, 75 \%$ and $100 \%$, while the factors that varied were farm gate prices.

The value of transplanted were the main cost items for all treatments, (39\% of total production costs), followed by the value of plastic about (19.5\% of the total production costs), while the value of sterilisation came in the third place about (14.7\% of total production costs) for the first season. For the second season, the value of transplanted where the main cost items for all treatments, (38.5\% of total production costs), followed by the value of plastic about $(19.0 \%$ of the total production costs), while the value of sterilisation came in the third place about (14.3\% of total production costs). 


\section{Total return}

The total return from different treatment combinations in the first season ranged between minimum USD 921.4 and maximum USD 1570.5 (Table 7). The highest total return USD 1570.5 was obtained with 1.00 ETc and black mulch, and the lowest total return USD 921.4 was obtained with 0.50 ETc and control. The total return from different treatment combinations in the second season ranged between minimum USD 202.81 and maximum USD 352.63 (Table 7). The highest total return USD 1719.4 was obtained with 1.00 ETc and black mulch, and the lowest total return USD 1015.2 was obtained with $0.50 \mathrm{ETc}$ and control.

\section{Gross margin}

The presented results in table 7 show that the gross margins of different treatment combinations in the first season ranged between a minimum of USD -226.7 and a maximum of USD 416.8. The highest gross margin of USD 416.8 obtained with 1.00 ETc and black mulch, and the lowest gross margin of USD -226.7 obtained with 0.50 ETc and control. The presented results in table 7 show that the gross margins of different treatment combinations in the second season ranged between a minimum of USD -164.4 and a maximum of USD 533. The highest gross margin USD 533 was obtained with 1.00 ETc and black mulch, and the lowest gross margin USD -164.4 was obtained with 0.50 ETc and control.

\section{Benefit cost analysis}

Among the different treatments, the highest BCA in the first season was recorded 1.36 in 1.00 ETc with black mulch; while, the lowest BCA in the first season was recorded 0.8 in 0.50 ETc with control (Table 7). Among the different treatments, the highest $\mathrm{BCA}$ in the second season was recorded 1.45 in 1.00 ETc with black mulch; meanwhile, the lowest BCA in the first season was recorded 0.86 in 0.50 ETc with control (Table 7).

Table-6. Total production costs analysis of sweet paper due to different levels of irrigation $\left(540 \mathrm{~m}^{2}\right)$ during 2014 and 2015 seasons (USD)

\begin{tabular}{|c|c|c|c|c|c|c|c|c|c|c|c|c|}
\hline $\begin{array}{c}\text { Treatment } \\
\text { combination }\end{array}$ & $\begin{array}{c}\text { Land } \\
\text { preparation }\end{array}$ & Transplants & Irrigation & Chemicals & Manure & Insecticides & Plastic & Maintenance & Sterilization & $\begin{array}{c}\text { Threads } \\
\text { and pillars }\end{array}$ & Labour & $\begin{array}{l}\text { T. variable } \\
\text { costs }\end{array}$ \\
\hline \multicolumn{13}{|c|}{ First season } \\
\hline $\begin{array}{c}50 \% \\
\text { Control }\end{array}$ & 16.89 & 337.84 & 16.89 & 76.01 & 45.05 & 101.35 & 225.23 & 13.51 & 168.92 & 33.78 & 112.61 & 1148.1 \\
\hline $\begin{array}{c}\text { Transparent } \\
\text { mulch }\end{array}$ & 16.89 & 337.84 & 16.89 & 76.01 & 45.05 & 101.35 & 225.23 & 13.51 & 168.92 & 33.78 & 112.61 & 1148.1 \\
\hline Black mulch & 16.89 & 337.84 & 16.89 & 76.01 & 45.05 & 101.35 & 225.23 & 13.51 & 168.92 & 33.78 & 112.61 & 1148.1 \\
\hline $\begin{array}{c}75 \% \\
\text { Control }\end{array}$ & 16.89 & 337.84 & 19.71 & 76.01 & 45.05 & 101.35 & 225.23 & 13.51 & 168.92 & 33.78 & 112.61 & 1150.9 \\
\hline $\begin{array}{l}\text { Transparent } \\
\text { mulch }\end{array}$ & 16.89 & 337.84 & 19.71 & 76.01 & 45.05 & 101.35 & 225.23 & 13.51 & 168.92 & 33.78 & 112.61 & 1150.9 \\
\hline Black mulch & 16.89 & 337.84 & 19.71 & 76.01 & 45.05 & 101.35 & 225.23 & 13.51 & 168.92 & 33.78 & 112.61 & 1150.9 \\
\hline $\begin{array}{c}100 \% \\
\text { Control }\end{array}$ & 16.89 & 337.84 & 22.52 & 76.01 & 45.05 & 101.35 & 225.23 & 13.51 & 168.92 & 33.78 & 112.61 & 1153.7 \\
\hline $\begin{array}{c}\text { Transparent } \\
\text { mulch }\end{array}$ & 16.89 & 337.84 & 22.52 & 76.01 & 45.05 & 101.35 & 225.23 & 13.51 & 168.92 & 33.78 & 112.61 & 1153.7 \\
\hline Black mulch & 16.89 & 337.84 & 22.52 & 76.01 & 45.05 & 101.35 & 225.23 & 13.51 & 168.92 & 33.78 & 112.61 & 1153.7 \\
\hline \multicolumn{13}{|c|}{ Second season } \\
\hline $\begin{array}{c}50 \% \\
\text { Control }\end{array}$ & 19.71 & 337.84 & 18.02 & 78.83 & 45.05 & 101.35 & 225.23 & 15.77 & 168.92 & 33.78 & 135.14 & 1179.6 \\
\hline $\begin{array}{l}\text { Transparent } \\
\text { mulch }\end{array}$ & 19.71 & 337.84 & 18.02 & 78.83 & 45.05 & 101.35 & 225.23 & 15.77 & 168.92 & 33.78 & 135.14 & 1179.6 \\
\hline Black mulch & 19.71 & 337.84 & 18.02 & 78.83 & 45.05 & 101.35 & 225.23 & 15.77 & 168.92 & 33.78 & 135.14 & 1179.6 \\
\hline $\begin{array}{c}75 \% \\
\text { Control }\end{array}$ & 19.71 & 337.84 & 21.40 & 78.83 & 45.05 & 101.35 & 225.23 & 15.77 & 168.92 & 33.78 & 135.14 & 1183.0 \\
\hline $\begin{array}{l}\text { Transparent } \\
\text { mulch }\end{array}$ & 19.71 & 337.84 & 21.40 & 78.83 & 45.05 & 101.35 & 225.23 & 15.77 & 168.92 & 33.78 & 135.14 & 1183.0 \\
\hline Black mulch & 19.71 & 337.84 & 21.40 & 78.83 & 45.05 & 101.35 & 225.23 & 15.77 & 168.92 & 33.78 & 135.14 & 1183.0 \\
\hline $\begin{array}{c}100 \% \\
\text { Control }\end{array}$ & 19.71 & 337.84 & 24.77 & 78.83 & 45.05 & 101.35 & 225.23 & 15.77 & 168.92 & 33.78 & 135.14 & 1186.4 \\
\hline $\begin{array}{c}\text { Transparent } \\
\text { mulch }\end{array}$ & 19.71 & 337.84 & 24.77 & 78.83 & 45.05 & 101.35 & 225.23 & 15.77 & 168.92 & 33.78 & 135.14 & 1186.4 \\
\hline Black mulch & 19.71 & 337.84 & 24.77 & 78.83 & 45.05 & 101.35 & 225.23 & 15.77 & 168.92 & 33.78 & 135.14 & 1186.4 \\
\hline
\end{tabular}


Table-7. Total yield, total cost of production, total return, gross margin and BCA of sweet paper due to various irrigation levels during 2014 and 2015 seasons (USD)

\begin{tabular}{|c|c|c|c|c|c|c|c|c|c|c|}
\hline \multicolumn{6}{|c|}{ First season } & \multicolumn{5}{|c|}{ Second season } \\
\hline $\begin{array}{l}\text { Treatment } \\
\text { combinations }\end{array}$ & $\begin{array}{l}\text { Total yield } \\
\text { Tonne }\end{array}$ & $\begin{array}{l}\text { Total cost of } \\
\text { production }\end{array}$ & Total return & Gross margin & BCA & $\begin{array}{l}\text { Total yield } \\
\text { Tonne }\end{array}$ & $\begin{array}{l}\text { Total cost of } \\
\text { production }\end{array}$ & Total return & Gross margin & BCA \\
\hline \multicolumn{11}{|c|}{$50 \%$} \\
\hline Control & 2.64 & 1148.1 & 921.4 & -226.7 & 0.80 & 2.82 & 1179.6 & 1015.2 & -164.4 & 0.86 \\
\hline $\begin{array}{c}\text { Transparent } \\
\text { Mulch }\end{array}$ & 3.084 & 1148.1 & 1076.3 & -71.8 & 0.94 & 3.324 & 1179.6 & 1196.6 & 17.0 & 1.01 \\
\hline Black mulch & 3.216 & 1148.1 & 1122.4 & -25.7 & 0.98 & 3.6 & 1179.6 & 1296.0 & 116.4 & 1.10 \\
\hline \multicolumn{11}{|c|}{$75 \%$} \\
\hline Control & 3.024 & 1150.9 & 1055.4 & -95.5 & 0.92 & 3.792 & 1183.0 & 1365.1 & 182.1 & 1.15 \\
\hline $\begin{array}{l}\text { Transparent } \\
\text { Mulch }\end{array}$ & 3.42 & 1150.9 & 1193.6 & 42.7 & 1.04 & 4.14 & 1183.0 & 1490.4 & 307.4 & 1.26 \\
\hline Black mulch & 3.756 & 1150.9 & 1310.8 & 159.9 & 1.14 & 4.356 & 1183.0 & 1568.2 & 385.2 & 1.33 \\
\hline \multicolumn{11}{|c|}{$100 \%$} \\
\hline Control & 3.708 & 1153.7 & 1294.1 & 140.4 & 1.12 & 4.116 & 1186.4 & 1481.8 & 295.4 & 1.25 \\
\hline $\begin{array}{l}\text { Transparent } \\
\text { Mulch }\end{array}$ & 4.212 & 1153.7 & 1470.0 & 316.3 & 1.27 & 4.524 & 1186.4 & 1628.6 & 442.3 & 1.37 \\
\hline Black mulch & 4.5 & 1153.7 & 1570.5 & 416.8 & 1.36 & 4.776 & 1186.4 & 1719.4 & 533.0 & 1.45 \\
\hline
\end{tabular}

Farm gate price per tonne in the first season $=$ US\$ 349. - Farm gate price per tonne in the second season $=$ US\$ 360.

\section{CONCLUSION}

From the present work it could be conclude that using PE mulch, especially black mulch, is considered useful for encouraging sweet pepper plant vegetative growth and getting high total yield. The use of 1.00 ETc with PE mulches is useful for increasing the early and total sweet pepper yield. This study serves as a guide for production practices and costs of production and profitability for growers, prospective growers, agriculture lenders, educators and others involved or have interest in fresh market sweet pepper production. The cost and return analysis indicated that the highest BCA (1.36 and 1.45) were obtained from the 1.00 ETc with black mulch in the first and second seasons, respectively.

\section{REFERENCES}

Abdrabbo, M. A. A., A. A. Farag and M. K. Hassanein.2009. Irrigation requirements for cucumber under different mulch colors. Egypt. J. Hort. 36, 333- 346.

Abdrabbo, M. A. A., A. A. Farag, M. K. Hassanein and A. F. Abou-Hadid. 2010. Water consumption of eggplant under different microclimate. J. Biol. Chem. Environ. Sci., 5(3), 239255.

Abdrabbo, M. A. A. F. A. Hashem, M. A. Abul-Soud and Shaimaa H. Abd-Elrahman. 2015. Sustainable production of cabbage using different irrigation levels and fertilizer types affecting some soil chemical characteristics. International Journal of Plant \& Soil Science. 8 (1): 1-13.
Abdrabbo, M. A. A., M. A. Medany. E. M. Abdelmoneim. A. F. Abou-Hadid.2005. Fertigation management of cucumber plants under plastic houses. Egypt. J. Hort. 32: 1-13.

Abou-Hadid, A.F. and A. S. El-Beltagy.1992. Water balance under plastic house conditions in Egypt. Acta Horticulture 303:61-72.

Allen, S.E. (1974) Chemical Analysis of Ecological Materials. Black-Well, Oxford, 565.

Bonnano, A.R. and Lamont, W.J.Jr. (1987) Effect of polyethylene mulches, irrigation method, and row covers on soil and air temperature and yield of muskmelon. J. Am. Soc. HortSci., 112, 735-738.

Chapman, H.D. and Pratt, F. (1961). Methods of analysis for soils, plants and water. Univ. of Calif., 35, 6 - 7.

Cooper, A.J. (1973) Root temperature and plant growth, A Review. Commonwealth Agr. Bur., Slough, England.

EI-Dolify, M.M., M.A. Abdrabbo, A. Abou EI-yazied and M. E. ldeeb.2016. Effect of using soil conditioners on tomato yield and water use efficiency. J. Agrie. Sei., 24(1),195-204.

FAO (1980) Soil and plant analysis. Soils Bulletin, 38, 2-250.

FAO (1982) Crop water requirements irrigation and drainage. Paper No. 24, Rome Italy.

Farag A. A., M. A. A. Abdrabbo, and M. K Hassanein. 2010. Response of cucumber for mulch colors and phosphorus levels under greenhouse. Egypt J. Hort. 37, 1:53-64.

Fonsecal, I.C., Klar, A.E. Goto, R. and Nevesl, C.S. (2003) Colored polyethylene soil covers and grafting effects on cucumber flowering and yield. Scientia Agricola, 60, 643-649.

Gittinger, J. P. (1982). Economic analysis of agricultural 
projects. Washington: The Johns Greene, W. (2003). Econometric Analysis, Upper Saddle River, NJ: Prentice Hall.

Hashem F.A., M.A.A. Abdrabbo, S. Abou-El-Hassan, and M.A. Abul-Soud. 2014. Maximizing water use efficiency via different organic mulches and irrigation levels. Research Journal of Agriculture and Biological Sciences, 10(2): 109-117

Israelsen, O.W. and Hansen, V.E. (1962) Irrigation Principles and Practices, 3rd ed John Wiley and Sons, Inc New York, London.

Karam Farrag, Mohamed A. A. Abdrabbo and Sabry A. M. Hegab.2016. Growth and productivity of potato under different irrigation levels and mulch types in the North West of the Nile Delta, Egypt. Middle East Journal of Applied Sciences, 6: 774786.

Kirda, C.C., Dasgan, T.Y. Kaman, S., Ekici, H. B. Derici, M. R. and Ozguven, A. I. (2004) Yield response of greenhouse grown tomato to partial root drying and conventional deficit irrigation. Agricultural Water Management, 69, 191-201.

Lamont, W.J. (1993) Plastic mulches for the production of vegetable crops. HortTechnology, 3, 35-39.

Liakatas, A., Clark, J.A. and Monteith, J.L. (1986) Measurements of the heat balance under plastic mulches. Agricultural and Forest Meteorology, 36, 227-239.

Marouelli, W.A. and Silva, W.L. (2005) Drip irrigation frequency for processing tomatoes during vegetative growth stage. Pes. Agropec. Brasil., 40, 661-666.

Ngouajio, M., Wang, G. and Goldy, R. (2007). Withholding of drip irrigation between transplanting and flowering increases the yield of field-grown tomato under plastic mulch Agric. Water Management, 87, 285 - 291.

Pan, H.Y., Fisher, K.J. and Nichols, M.A. (1999) Effect of mulch and row covers on yield of process tomatoes. Acta Horticulturae., 487, 145-150.

Rajbir Singh, Kumar,S., Nangare,D.D and Meena, M.S. 2009. Drip irrigation and black polyethylene mulch influence on growth, yield and water-use efficiency of tomato. African Journal of Agricultural Research. 4(12): 1427-1430.

Snedicor, G. W. and Cochran, W. G. (1981) Statistical Methods. 7thed. Iowa State Univ. Press, Iowa, USA.

Soltani, N., Anderson, J.L. and Hamson, A.R. (1995) Growth and analyses of watermelon plants with mulches and row covers. J. Am. Soc. Hort. Sci., 120, 1001-1009.

Taber, H.G. (1993). Early muskmelon production with wave length-selective and clear plastic mulches. HorTecnhology, 3, 78-80.

Watanabe, F. S. and Olsen, S. R. (1965) Test of an ascorbic acid method for determining phosphorus in water and $\mathrm{Na} \mathrm{HCO} 3$ extracts from soil. Soil Sci. Soc. Amer. Proc., 29, 677-678.

Zakher, A.G., and M. A. A. Abdrabbo. 2014. Reduce the harmful effect of high temperature to improve the productivity of tomato under conditions of newly reclaimed land. Egypt. J. Hort. Vol. 41, No.2, pp.85 -97. 